\title{
Blue Grama [Bouteloua gracilis] Response tc Fertilization of a Claypan Soil in the Greenhouse
}

\author{
E.M. WHITE, F.R. GARTNER, AND R. BUTTERFIELD
}

\begin{abstract}
Blue grama, grown in situ on the upper $12 \mathrm{~cm}$ of a claypan soil in the greenhouse, had greater growth when minor elements were added with $N, P$, and $K$. $N$ fertilized plants produced significantly less forage than NPK-fertilized ones but slightly more than unfertilized plants. Renovation of claypan areas to increase water infitration may need to be accompanied by fertilization with minor elements, particularly on old landscapes where soil weathering has been intense.
\end{abstract}

Some claypan areas support depauperate blue grama (Bouteloua gracilis) plants even though the known grazing history has been light or dormant-season use. Forage production on these sites during seasons with above average precipitation does not increase as much as on sites where blue grama plants are more vigorous. Mechanical treatments, such as ripping or contour furrowing, increase the amount of soil water for plant growth. Yet, low soil fertility of claypans may mask the effect of added soil water following mechanical treatment. Thi effect of soil fertility on blue grama growth was investigated in the greenhouse where a water deficit would not limit growth.

\section{Methods}

The upper $12 \mathrm{~cm}$ of a claypan soil with blue grama plants intact was extracted from a claypan range site in October, 1979. Soil and plants were placed in 13-cm plastic pots. The semidormant plants were grown in the greenhouse for about 2 months to acclimate the plants. Six replications of 4 treatments were prepared. Pots were weighed and plant crown areas measured so each potted plant in a replication was similar to the other 3 . The treatments were: no fertilizer, N, NPK, and NPK with minor elements (ME). Hoagland's formulation for nut rient solutions was used. Equal amounts of $\mathbf{N}$ or $\mathbf{P}$ and $\mathrm{K}$ were added to each treatment that received these elements but actual amounts applied were not recorded for this qualitative study. The minor elements added were $\mathrm{B}, \mathrm{Mn}, \mathrm{Cl}, \mathrm{Zn}$, $\mathrm{S}$, and $\mathrm{Cu}$.

Distilled water was used in all nutrient solutions and to furnish water as needed to pots with vigorous plant that used more water than was supplied in the nutrient solutions. The pots were placed in plastic dishes so that leachate solutions could be returned to the soil surface. Thus, difference in response to a treatment could not be attributed to leaching of the soil.

Flower stalk heights were measured and the stalks cut off at the soil level, dried at $70^{\circ} \mathrm{C}$, and weighed. Maximum leaf heights were measured and half the estimated total top growth was clipped, dried at $70^{\circ} \mathrm{C}$, and weighed. After the initial clipping, clippings were made when regrowth slowed. After the fifth clipping, soils in the pots were air dried, weighed, crushed, and screened $(<2 \mathrm{~mm})$ to

Authors are professor of plant science (soils), South Dakota State Univ., Box 2207A. Brookings 57007; and associate professor and research assistant of animal science, South Dakota State University Agricultural Research and Extension Center, Rapid City 57701. This report is S. Dakota Agr. Exp. Sta. Journal No. 1752.

Manuscript received March 30, 198I. remove pebbles and plant remains. Pebbles were washed, drie and weighed to adjust the soil weights to a stone-free basi Methods used for soil analyses have been described (White et a 1981). Orthogonal comparisons in the analysis of variance we tested by the error mean square except for flower stalk measur ments. Because the error variance of the flower stalks from tl unfertilized treatment likely is not the same as in the other trea ments, the error sum of squares was partitioned (Steele and Torr 1960) for the orthogonal comparisons.

\section{Results and Discussion}

Attributes of fertilized plants were significantly larger than tho: of the unfertilized plants in all 5 harvests (Table 1). Leaf weigh increased progressively from treatments with $\mathrm{N}$, to NPK, and 1 $\mathrm{NPK}+\mathrm{ME}$. The plants receiving ME had a more vigorous appea ance in the greenhouse although flower stalk production tended 1 be greater with NPK lacking ME.

Table 1. Means of 4 growth measurements of blue grama for 5 consecuti harvests of pots treated with different nutrient solutions.

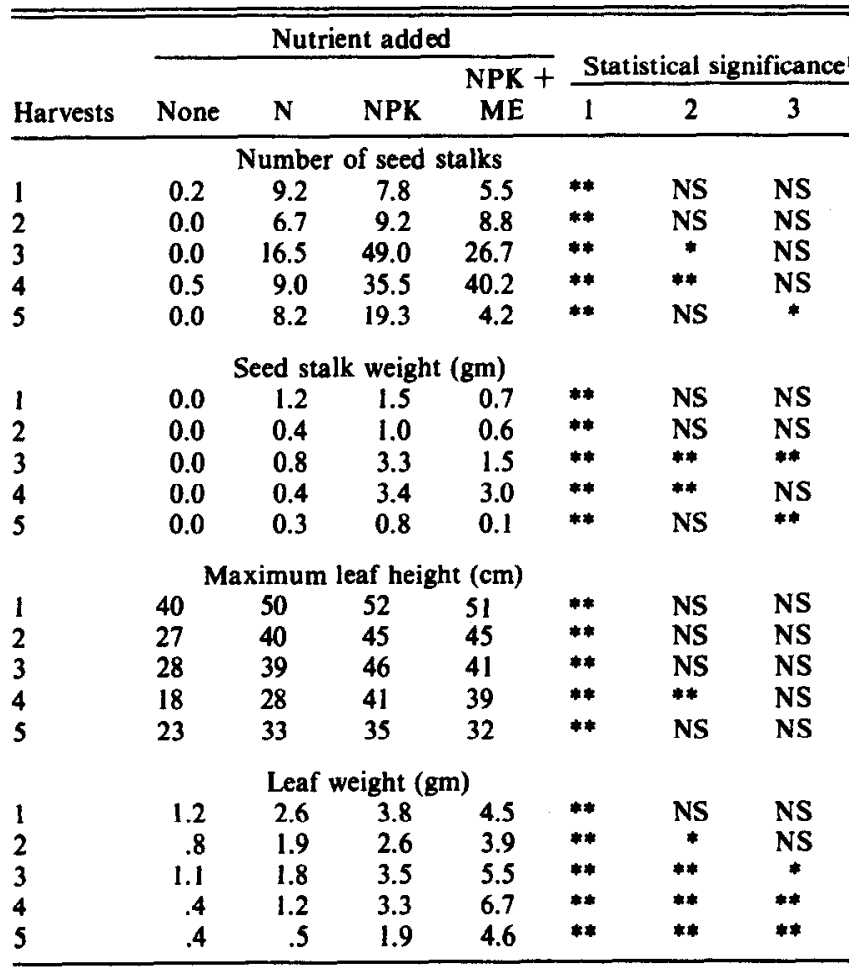

'Órthogonal comparisons were: 1 . None vs. N, NPK and NPK + ME; 2 . N vs. N] and NPK + ME; and 3. NPK vs. NPK + ME. Analyses are: NS-not significa *-significant at $p=0.05$, and **-significant at $p=0.01$. 
Table 2. Mean analyses from soils used in pots of the 6 greenhouse replications for each treatment.

\begin{tabular}{|c|c|c|c|c|c|c|c|}
\hline \multirow{2}{*}{$\frac{\text { Property }}{\text { Extractable cations }}$} & \multicolumn{4}{|c|}{ Nutrients added } & \multirow{2}{*}{\multicolumn{3}{|c|}{$\begin{array}{l}\text { Statistical significancel } \\
\text { Orthogonal comparisons }\end{array}$}} \\
\hline & None & $\mathbf{N}$ & NPK & $\mathbf{N P K}+\mathbf{M E}$ & & & \\
\hline $\begin{array}{l}\text { Extractable cations } \\
\mathrm{Ca}-\mathrm{meg} / 100 \mathrm{~g} \\
\mathrm{Mg} \\
\mathrm{K} \\
\mathrm{Na} \\
\mathrm{CEC} \\
\mathrm{ESP}-\%\end{array}$ & $\begin{array}{r}12.8 \\
9.6 \\
1.4 \\
3.1 \\
21.2 \\
14.2\end{array}$ & $\begin{array}{r}13.5 \\
7.7 \\
2.2 \\
2.2 \\
17.7 \\
12.7\end{array}$ & $\begin{array}{r}12.5 \\
11.8 \\
2.7 \\
2.4 \\
18.9 \\
12.4\end{array}$ & $\begin{array}{r}12.4 \\
10.7 \\
1.7 \\
2.6 \\
19.0 \\
13.6\end{array}$ & $\begin{array}{c}1 \\
\text { NS } \\
\text { NS } \\
* \\
\text { NS } \\
\text { NS } \\
\text { NS }\end{array}$ & $\begin{array}{c}2 \\
\text { NS } \\
* \\
\text { NS } \\
\text { NS } \\
\text { NS } \\
\text { NS }\end{array}$ & $\begin{array}{c}3 \\
\text { NS } \\
\text { NS } \\
* \\
\text { NS } \\
\text { NS } \\
\text { NS }\end{array}$ \\
\hline $\begin{array}{l}\text { Total Analyses } \\
\mathrm{Ca}-\% \\
\mathrm{Mg} \\
\mathrm{K} \\
\mathrm{Na} \\
\mathrm{P}-\text { ppm }\end{array}$ & $\begin{array}{l}0.65 \\
0.76 \\
0.71 \\
0.12 \\
618\end{array}$ & $\begin{array}{l}0.56 \\
0.65 \\
0.65 \\
0.09 \\
-\end{array}$ & $\begin{array}{l}0.56 \\
0.77 \\
0.78 \\
0.10 \\
625\end{array}$ & $\begin{array}{l}0.59 \\
0.71 \\
0.61 \\
0.09 \\
617\end{array}$ & $\begin{array}{c}\text { NS } \\
\text { NS } \\
\text { NS } \\
* \\
-\end{array}$ & $\begin{array}{l}\text { NS } \\
\text { NS } \\
\text { NS } \\
\text { NS } \\
-\end{array}$ & $\begin{array}{l}\text { NS } \\
\text { NS } \\
\text { NS } \\
\text { NS } \\
-\end{array}$ \\
\hline $\begin{array}{l}\text { pH } \\
\text { Cond.-mho } / \mathrm{cm} \\
\text { Sat.-\% } \\
\text { Soil weight-kg }\end{array}$ & $\begin{array}{c}7.5 \\
0.7 \\
41 \\
2.0\end{array}$ & $\begin{array}{c}7.1 \\
4.2 \\
32 \\
1.9\end{array}$ & $\begin{array}{c}7.4 \\
3.9 \\
40 \\
1.9\end{array}$ & $\begin{array}{c}7.6 \\
1.8 \\
40 \\
2.0\end{array}$ & $\begin{array}{l}\text { NS } \\
* * \\
\text { NS } \\
\text { NS }\end{array}$ & $\begin{array}{l}* \\
* * \\
\text { NS } \\
\text { NS }\end{array}$ & $\begin{array}{l}\text { NS } \\
* * \\
\text { NS } \\
\text { NS }\end{array}$ \\
\hline
\end{tabular}

'See Table 1 for footnotes.

A 3-way analysis of variance of total top growth that included the factors of harvests, replications, and treatments was very highly significant for all main effects and interactions. The 3 orthogonal comparisons shown in Table 1 also were very highly significant for the treatments in the 3-way analysis. Leaf weight differences between the NPK and NPK + ME treatments tended to increase with each harvest. Possibly ME are made unavailable in the soil until the fixing capacity is satisfied. Leaf and flower heights were not clearly related to the weight parameters.

Differences in extractable and total $\mathrm{Ca}, \mathrm{Mg}, \mathrm{K}$, and $\mathrm{Na}$ in the soils, at the end of the experiment, were slight among the different treatments (Table 2). Conductivity was highest for the $\mathrm{N}$ treatment and decreased from the NPK to the NPK + ME treatment and was lowest in soils receiving no fertilizer. Presumably, the salts, which cause conductivity to be high, accumulated more from the fertilizer in the $\mathrm{N}$ treatment because fewer were used for growth. Correla-

Table 3. Significance of the correlations of blue grama growth with the properties of the soils in the pot at the conclusion of the experiment.

\begin{tabular}{|c|c|c|c|c|c|}
\hline \multirow{2}{*}{$\begin{array}{l}\text { Soil } \\
\text { Property }\end{array}$} & & \multicolumn{4}{|c|}{ Fertility treatment ${ }^{1}$} \\
\hline & & None & $\mathrm{N}$ & NPK & NPKT \\
\hline & & \multicolumn{4}{|c|}{ Total bluegrama top growth } \\
\hline \multirow[t]{4}{*}{ Extractable } & $\mathrm{Ca}$ & NS & NS & $\div$ & NS \\
\hline & $\mathrm{Mg}$ & NS & NS & NS & NS \\
\hline & $\mathbf{K}$ & NS & NS & $* *$ & NS \\
\hline & $\mathrm{Na}$ & NS & NS & NS & NS \\
\hline \multirow[t]{5}{*}{ Total } & $\mathrm{Ca}$ & NS & NS & NS & NS \\
\hline & $\mathbf{M g}$ & NS & NS & NS & NS \\
\hline & $\mathbf{K}$ & NS & NS & NS & NS \\
\hline & $\mathbf{N a}$ & NS & NS & NS & NS \\
\hline & $\mathbf{P}$ & & & & \\
\hline pH & & NS & NS & NS & NS \\
\hline Conductivity & & NS & NS & $* *$ & $*$ \\
\hline Soil weight & & NS & NS & NS & $*$ \\
\hline ESP & & NS & NS & NS & NS \\
\hline CEC & & NS & NS & NS & NS \\
\hline Sat. $\mathrm{H}_{2} \mathrm{O}$ & Percent & NS & NS & NS & NS \\
\hline
\end{tabular}

'Correlations are NS-not significant, *-significant at $\mathrm{p}=0.05$, or **-significant at $\mathrm{p}=0.01$. tions between soil conductivity and total top growth were significant for both the NPK and NPK + ME treatments, but not for the other two treatments where a lack of $P, K$, or ME probably limited growth (Table 3). The problem of whether or not blue grama growth was limited either initially by a high soil salt content or salt accumulated because some fertilizer element was deficient cannot be resolved by this data.

\section{Application of the Data}

Ripping or furrowing of claypan soils may need to be accompanied by applications of $P$ or $K$ and ME to stimulate blue grama growth to effectively use the increased soil water. Evidence is lacking in the literature that ME limits plant growth on claypan soils, possibly because ME may be needed only where soils are highly weathered. Many soil landscapes in western South Dakota and in other parts of the Great Plains were formed at the time of the Illinoian or the Kansan stage of the Pleistocene. These landscapes in western South Dakota have been dissected by more recent stream dissection (White 1964a) leaving many of the older soil areas unaffected (White 1964b). Some claypan soils on these older landscapes have undergone prolonged weathering with most of the exchangeable $\mathrm{Na}$ having been leached from the main part of the claypan (White 1961). Range scientists renovating claypan soils on old landscape should consider adding fertilizers containing ME, at least on an experimental basis.

\section{Literature Cited}

White, E.M. 1961. Calcium-solodi or planosol genesis from solodizedsolonetz. Soil Sci. 91:175-177.

White, E.M. 1964a. 1964. Age relationship of wavy-gilgaied and nongilgaied soils in western South Dakota. Soil Sci. Soc. Amer. Proc. 28:798801 .

White, E.M. 1964b. Post-Illinoian age for Missouri River in South Dakota proposed from relationship to a White River terrace. Amer. J. Sci. 262:494-496.

White, E.M., F.R. Gartner and R. Butterfield. 1981. Range claypan soil improvement: Response from furrowing and riping in northwestern South Dakota. J. Range Manage. (In Press).

Steele, R.G.D. and J.H. Torrie. 1960. Statistics. McGraw-Hill Book Co., Inc. New York 